\title{
Malignant Nodular Hidradenoma: Isolated Case Report and Review of Literature
}

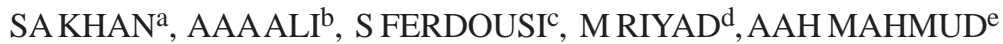

\begin{abstract}
Summary:
Malignant Nodular Hidradenoma is an infrequent highly malignant, primary skin tumor derived from eccrine sweat glands. It has an aggressive course, with high recurrence, high rate of metastases and has very poor prognosis. It has been described as an "orphan"neoplasm. The tumor is similar to its benign counterpart but had additional features such as surface ulceration, numerous mitotic figures and infiltrative growth pattern. Pre-operative diagnosis is difficult
\end{abstract}

\section{Intoduction :}

Malignant tumors of the sweat glands represent rare oncological entites, characterized by non-specific clinical presentation and equivocal pathological features. Their precise diagnosis and histological classification can be very difficult. It is an extremely rare tumor with less than 50 cases reported ${ }^{1}$.

Hidradenomas arise as intradermal nodules from eccrine sweat glands. Ultrastructural and enzyme histochemical studies have shown nodular hidradenomas to be intermediate between eccrine poroma and eccrine spiradenoma ${ }^{2}$. The histology of the malignant hidradenoma resembles of it's benign counterpart. The

a. Dr. Sadia Armin Khan, Assistant Professor, Department of Surgery, Ad-din Women's Medical College Hospital

b. Professor Abu Ahmed Ashraf Ali, Professor of Surgery, Addin Women's Medical College Hospital

c. Dr. Shamima Ferdousi, Associate Professor, Department of Pathology, Ibrahim Medical College Hospital

d. Dr. Mahmud Riyad, Associate Professor, Department of Surgery, Ad-din Women's Medical College Hospital

e. Dr. Ahmed-Al-Hasan Mahmud, Registar, Department of Surgery, Ad-din Women's Medical College Hospital.

Address of Correspondence: Dr. Sadia Armin Khan, Assistant Professor, Department of Surgery, Ad-din Women's Medical College Hospital, Mobile: 01720809726, e-mail: arminbd @yahoo.com

Received: 30 September, 2014 Accepted: 29 November, 2015 by the fine needle aspiration cytology. Malignant nodular hidradenoma of chest wall in 35 years old women, who presented to us with a recurrent rapidly growing swelling over chest wall that grew rapidly over two months after first excision. Tissue diagnosis of first excised specimen was eccrine poroma that was similar to its benign counterpart.

Key words: sweat gland tumor, malignant hidradenoma, eccrine poroma, spiradenoma.

(J Bangladesh Coll Phys Surg 2016; 34: 100-103)

criteria for malignancy include poor circumscription, presence of nuclear atypia, mitotic activity, presence of predominantly solid cell islands, infiltrative growth pattern, necrosis, and angio-lymphatic permeation ${ }^{3-5}$. We report a case of malignant nodular hidradenoma in a middle aged woman who presented with a recuurent swelling in right side of lower chest wall.

\section{Case report :}

A 35 years old female presented to us with swelling over right side of chest wall. The swelling was excised and sent for histopathology. The report was ecccrine proroma. But it recurred after two months. The swelling was rapidly increasing in size over the last one and half months. The mass became significantly prominent over the last 15 days prior to presentation resulting in discomfort.

Physical examination revealed a large lobulated mass about $20 \mathrm{cmx} 15 \mathrm{~cm}$ in size, without ulceration. It was hard, non-mobile, non-fluctuant and adherent to the old scar. The draining area showed no palpable lymphnode. General examination including lungs and liver were normal. Per-operatively, a hard fibrous tumor was observed to infiltrate the muscle but not to underlying ribs. Wide local excision with $1 \mathrm{~cm}$ marginal clearance of healthy surrounding tissue was performed along with primary closure. Biopsy was sent to pathological examination. 


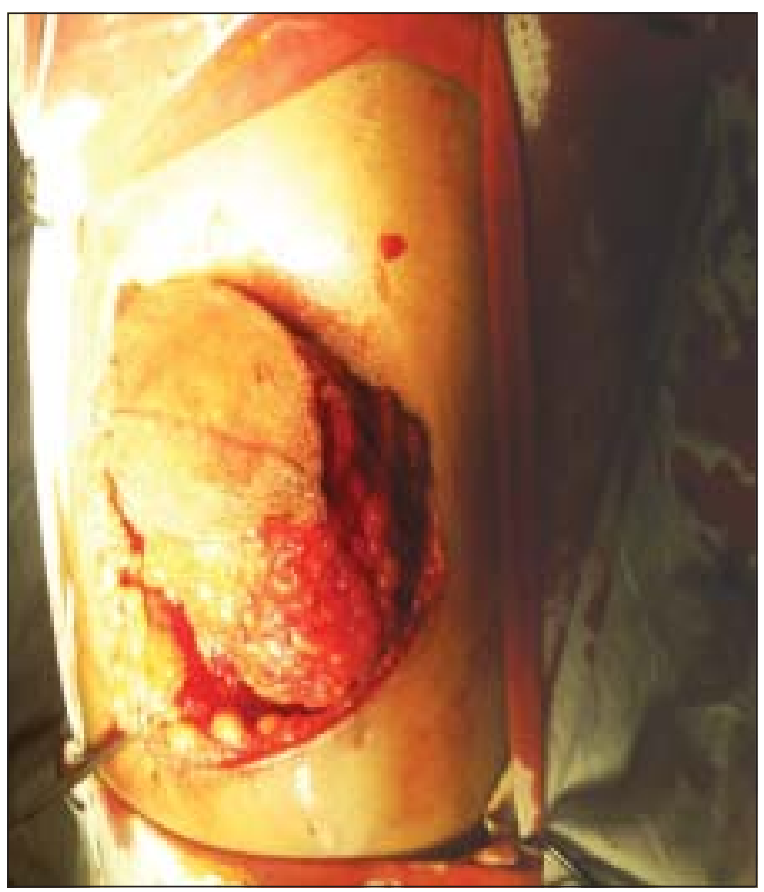

Per-operative view showing large mass adhere to overlying scar mark and surrounding tissue
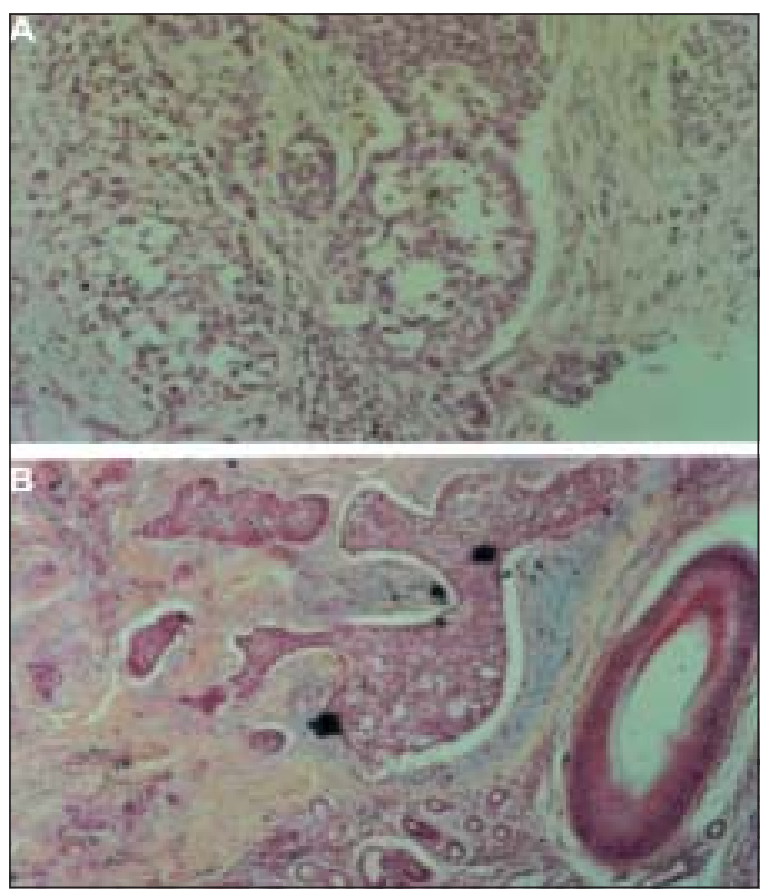

Microscopical image of the clear cell hidradenoma arising from the anterior abdominal wall. A) Elements of tubular and solid neoplastic configuration arising in the vicinity of a hair follicle. B) Malignant cells with clear, transparent cytoplasm and round nucleus.

\section{Pathological findings :}

GROSS : Partly skin covered with grayish yellow mass measuring $18 x 11 \times 7 \mathrm{~cm}$. Skin surface shows a part of old incision mark measuring $5.5 \mathrm{~cm}$ in length. The cut surface shows a grey brown lobulated tumor with area of cystic change.

Microscopic description : The dermis presents a malignant tumor with infiltrating border made of polygonal cells showing mild to moderate pleomorphism. Mitotic figures are frequent. Areas of necrosis are seen. The deep resection margin and peripheral resection margins are free from tumor. The tumor exhibited infiltrative growth pattern. A diagnosis of malignant nodular hidradenoma was made.

\section{Discussion :}

The recognition of hidradenoma as a distinct entity was first reported in 1941 by Mayer, whereas the term "clear cell hidradenoma” was proposed in 1954 by Keasby and Hadley ${ }^{6}$. The malignant form of hidradenoma is extremely rare, with less than 50 cases ever reported in the literature. All these cases were characterized by a significant rate of locoregional recurrence. Some patients developed distant metastatic spread as well ${ }^{7-8}$.

The disease is usually expressed as a small intradermal mass which remains inactive for a long period of time before increasing in size. Its aggressive behavior is more apparent after each local relapse with faster growth and invasion of the surrounding tissues. In most cases, no epidermal participation is encountered. Hidradenoma usually affects middle-aged women, although its malignant form shows no age or gender predilection ${ }^{9-11}$.

Malignant hidradenoma is usually found in the scalp, face or anterior surface of the trunk. These lesions tend to metastasized and may cause death ${ }^{12}$.

Although there is insufficient evidence in the literature, the recurrence rate may be estimated at about $50 \%$ and metastasis rate is about $60 \%$ including metastasis to regional nodes, bone, viscera and skin ${ }^{12}$.

Histologically, clear cell hidradenoma seems to originate from the ductal epithelium of the sweat glands, whereas histogenetically it appears to represent a transitional tumor, sharing features of eccrine poroma and eccrine spiradenoma ${ }^{9}$.

Malignant nodular hidradenoma are usually larger, asymmetrical, and show invasion into surrounding 
tissue. In addition, there may be angio-lymphatic invasion. Mitosis are usually easily detected, and some may be atypical. Tumor necrosis, areas of high cellularity, and focal and diffuse areas of marked cytological atypia in which differentiated elements are unrecognizable are present in some examples. In some cases of Malignant nodular hidradenomas, nuclear anaplasia may be only slight to moderate or even absent in the both primary tumors and the metastasis. Nuclear anaplasia , if present, may be limited to the clear cells or affect both the polyhedral and clear cells ${ }^{12}$.

The recognition of the eccrine origin of a malignant hidradenoma may be accomplished through specific immunohistochemical techniques, a positive PAS stain, as well as with the presence of lobules with epidermal differentiation 8,13 .

Sweat-glands neoplasms generally arise from the eccrine cellular lineage, they exhibit cellular growth patterns that may further influence the neoplasm's architecture. Hidradenoma may exhibits both cystic and solid features and that is why it enters on differential diagnosis with apocrine tumors; in fact there are divergent opinions on the primitive cellular lineage. The issue is complicated by the coexistence of eccrine and apocrine cells inside cutaneous hamartomas or inside adnexal tumors with mixed differentiation (follicular and sebaceous) ${ }^{14,15}$.

Malignant clear cell hidradenoma usually develops de novo and invades the dermis and subcutaneous tissue. Surprisingly, it might share significant histopathological features with its benign form. The mitotic index may not be representative or may affect only a small cellular subpopulation. Thereafter, the diagnosis of malignancy through standard pathological examination may prove extremely difficult ${ }^{16}$.

In our case, it was interesting to note that, in contrast to the final diagnosis, previous pathology reports had ascertained the presence of an eccrine poroma. The latter is a benign tumor of the sweat glands with similar clinical presentation and equivocal enzyme reactions, which pose tremendous diagnostic dilemmas ${ }^{17}$. Because of the rarity of these oncological entities, as well as their histopathological similarity, it is almost impossible to define whether a malignant clear cell hidradenoma had been developed from a benign eccrine poroma or was the correct diagnosis from the beginning.
The most recent reports support the fact that malignant clear cell hidradenoma should be considered as a distinct entity rather than the result of a malignant transformation of its benign type, underlining the importance of a precise initial diagnosis ${ }^{18,19}$. Rosen et al. ${ }^{20}$ presented a case of a clear cell hidradenoma of the eyelid complicated by multiple recurrences and invasion of nearby structures. Histologically, no atypia or increased nuclear mitoses were found. The precise identification of a benign or malignant hidradenoma, based on pathological examination, was not possible. Similar findings were noted in other case reports of clear cell hidradenoma ${ }^{21-26}$.

Surgical excision remains the therapeutic modality of choice. Wong et al. ${ }^{8}$ supported wide surgical resection with a least $2 \mathrm{~cm}$ of clear margins for both primary disease and local recurrences. Elective regional lymphadenectomy after lymphoscintigraphy should also be performed. The role of sentinel lymph node biopsy in the treatment of malignant hidradenoma is controversial. Locoregional recurrence even after wide surgical excision has been reported in more than $50 \%$ of cases, although overall and disease-free survival rates are hard to determine as the result of the very limited number of reported cases ${ }^{27}$. Adjuvant chemotherapy and radiotherapy have no impact in local control or survival ${ }^{28}$.

The use of Mohs micrographic surgery with superior evaluation of surgical margins has been utilized more recently as the primary treatment modality ${ }^{29}$. The use of sentinel lymph node biopsy also has been reported to be useful, especially given the propensity for the metastatic spread ${ }^{29}$.

Immunohistochemitry revealed strong positivity for Epithelial Membrane Antigen (EMA), Estrogen and Progesterone Receptors (EPR) and CEA. P63, CFDP-15 and C-erbB2 were negative. Ki67 decorated $40 \%$ of neoplastic cells, which has been sparked interest in treatment with hormone therapy. Schrçder et $\mathrm{al}^{30}$ reported the use of tamoxifen as adjuvant therapy for an estrogen receptor positive metastatic sweat gland adenocarcinoma. Further study has also been going on.

\section{Conclusion:}

Malignant clear cell hidradenoma is a rare oncological entity, with no particular clinical or histopathological features. It should be included in the differential 
diagnosis of dermal lesions with an aggressive behavior and multiple recurrences, despite aggressive surgical treatment.

\section{References:}

I. E. Liapakis, D.P. Korkolis, A. Koutsoumi, A. Fida, G. Kokkalis and P.P. Vassilopoulus: Malignant Hidradenoma: A Report of Two Cases and Review of the Literature. ANTICANCER RESEARCH 26: 2217-2220 (2006)

2. Agarwala NS, Rane TM, Bhaduri AS. Clear cell hidradenoma of the eyelid: A case report. Indian J Pathol Microbiol. 1999;42:361-3. [PubMed]

3. Headington JT, Niederhuber JE, Beals TF. Malignant clear cell acrospiroma. Cancer. 1978;41:641-7. [PubMed]

4. Mehregan AH, Hashimoto K, Rahbari H. Eccrine adenocarcinoma: A clinicopathologic study of 35 cases. Arch Dermatol. 1983;119:104-14. [PubMed]

5. Volmar KE, Cummings TJ, Wang WH, Creager AJ, Tyler DS, Xie HB. Clear cell hidradenoma: A mimic of metastatic clear cell tumors. Arch Pathol Lab Med. 2005;129:e1136. [PubMed]

6. Keasby LE and Hadley GG: Clear cell hidradenoma. Cancer 7: 934-951, 1954.

7. AshJey J, Smith-Reed M and Chernys A: Sweat gland carcinoma. Case report and review of the literature. Dermatol Surg 23: 129-133, 1997.

8. Wong TY, Suster S, Nogita T, Duncan LM, Dickersin RG and Mihm MC: Clear cell eccrine carcinomas of the skin. A clinicopathologic study of nine patients. Cancer 73: 1631-1643, 1994.

9. Lever WF and Schaumburg-Lever G: Histopathology of the Skin. 6th Edition. JB Lippincot, Philadelphia, pp. 557-585, 1983.

10. Lopez-Burbano LF, Cimorra GA, Gonzalez-Peirona E and A/Faro J: Malignant clear-cell hidradenoma. PRS 80: 300303, 1986.

11. Champion RH, Burton JL and Ebling FJG (eds.): Rook/ Wílkinson/Ebling. Textbook of Dermatology, 5th Edition,Blackwell Scientific Publications, Oxford pp. 1515-1518, 1992.

12. David E Elder: Lever's Histopathology of the Skin, $9^{\text {th }}$ Edition,907.

13. Johnson BI and Helwig EB Jr: Eccrine acrospiroma. Cancer 23:641-657, 1969.

14. Groben PA, Hitchcock MG, Leshin B, White WL (1999) Apocrine poroma: a distinctive case in a patient with nevoid basal cell carcinoma syndrome. Am J Dermatopathol 21: 31-33.

15. Harvell JD, Kerschmann RL, LeBoit PE (1996) Eccrine or apocrine poroma? Six poromas with divergent adnexal differentiation. Am J Dermatopathol 18: 1-9.
16. Hernandez-Perez E and Cruz FA: Clear cell hidradenocarcinoma:report of an unusual case. Dermatologica 153: 249-252, 1976.

17. Hashimofo K, Di Bella RJ and Lever WF: Clear cell hidradenoma. Arch Dermatol 96: 18-38, 1967.

18. Lopez-Burbano LF, Cimorra GA, Gonzalez-Peirona E and A/Faro J: Malignant clear-cell hidradenoma. PRS 80: 300303, 1986.

19. Ohta M, Hiramoto M, Fujii M and Togo T: Nodular hidradenocarcinoma on the scalp of a young woman: case report and review of literature. Dermatol Surg 9: 12651268, 2004.

20. Rosen Y, Kim B and Yermakov V: Eccrine sweat gland tumor of clear cell origin involving the eyelids. Cancer 36: 1034-1041, 1975.

21. Harada T, Muraoka M, Ishii M and Wakasa K: Malignant clearcell hidradenoma associated with pseudoepitheliomatous hyperplasia on the forehead. Ann Plast Surg 4: 443-444, 2003.

22. Yildirim S, Akoz T, Apaydin I, Ege GA and Gideroglu K: Malignant clear cell hidradenoma with giant metastasis to the axilla. Ann Plast Surg 1: 102, 2000.

23 Grossniklaus HE and Knight SH: Eccrine acrospiroma (clear cell hidradenoma) of the eyelid. Immunohistochemical and ultrastructural features. Ophthalmology 98: 347-352, 1991.

24. Herzberg AJ, Elenitsas R and Strohmeyer CR: An unusual case of early malignant transformation in a spiradenoma. Dermatol Surg 21: 731-734, 1995.

25. Biernat $\mathrm{W}$ and Biernat S: Cutaneuous adnexal carcinoma arising within a solitary cylindroma-spiradenoma. Am J Dermatopathol 18: 77-82, 1996.

26. Itoh T, Yamamoto $\mathrm{N}$ and Tokunaga M: Malignant eccrine spiradenoma with smooth muscle cell differentiation: histological and immunohistochemical study. Pathol Int 46: 887-893, 1996.

27. Touma D, Laporte M, Goosens A and Ledoux M: Malignant clear cell hidradenoma. Dermatology 186: 284286, 1993.

28. Stromberg BV, Thorne S, Dimino-Emme L, Katz DA and Rouse JW: Malignant clear cell hidradenoma: a case report and literature review. Nebr Med J 76: 166-170, 1991.

29. Tolland JP, Brenn T, Guldbakke KK, et al. Mohs micrographic surgery and sentinel lymph node mapping and estrogen receptor analysis for the treatment of malignant nodular hidradenoma. Dermatol Surg.2006; 32: 1294-1301.

30. Schrçder U, Driers V, Klussmann JP, et al. Successful adjuvant tamoxifen therapy for estrogen receptor positive metastasizing sweat gland adenocarcinoma: need a clinical trial? Ann Otol Rhinol Laryngol. 2004; 113(3, pt 1): 242-244. 